\section{Franklin Valley not so special?}

SIR - With the proposal to construct a dam that would flood the Franklin Valley in Tasmania, the archaeological content of the Franklin Valley caves received wide publicity (Nature 300, 679; 1982). Undoubtedly the finds make a valuable contribution to the study of prehistory, but in the context of the debate the perspective became distorted.

In depositions to the High Court in support of the Commonwealth's case it was claimed that the finds were unique and in one declaration Dr Rhys Jones asserted that " $\mathrm{it}$ is most unlikely that sites providing material of comparable archaeological value will be found in south west Tasmania outside the (Lower Franklin and Middle Gordon) limestone belts".

To test these statements and to assess their objectivity, the Hydro-Electric Commission's Geological Section conducted a search for similar caves outside the reservoir area during a two-week period in May 1983. Those conducting the search were convinced that the assertions were wrong, because the potential cave forming rock formations, the Precambrian, Ordovician and Devonian dolomites and limestones are widely distributed throughout the western half of the state. These formations occur in the broad valleys that lie between parallel ridges that are the dominant feature of the landscape. The valleys would have been readily accessible to Pleistocene man, during the period of interest some 20,000 years ago, when they were covered by grasslands or sclerophyll heath and sedgelands, and largely devoid of trees. Today these valleys are covered by dense rainforest and exploration is difficult.

We found five caves, with content similar to the Franklin Valley caves and considered to have the same archaeological significance, in widely separated areas. These caves are in the Andrew, Acheron, Florentine, Nelson and New River valleys. Given that the inland area was abandoned as a habitat about 15,000 years ago (K. Kiernan et al. Nature 301,28-32; 1983), it is reasonable to assume that the caves were occupied during the same period as the Franklin Valley caves. The archaeological evidence in the new caves includes large quantities of bones and teeth, split and burnt bones, charcoal fragments, stone artefacts and in one cave a flake of Darwin glass. An additional fifteen caves of possible archaeological significance were located.

The new caves have not been inspected by an archaeologist, because the Association of Consulting Archaeologists Incorporated advised its members not to take part in any recovery operation. Nevertheless, we are convinced of the worth and status of the new finds.

Archaeological investigations in the Lower Gordon area have so far concen- trated on the proposed storage area to the almost total exclusion of other potentially fruitful areas of search. Our cave study for instance revealed that there are over 1,000 known caves in the extensive cavernous formations, and in the coastal and midland sandstone formations. Very few of these have been inspected by an archaeologist. As a specific example, of the $\mathbf{3 3 5}$ known caves in the Florentine Valley, which is outside the Gordon reservoir area, only about 20 have been visited by an archaeologist. The scope for further research is considerable.
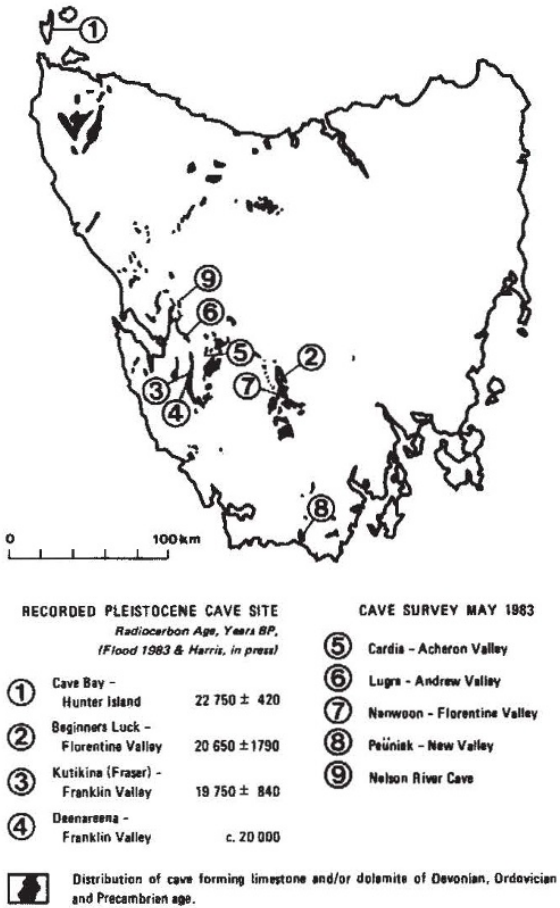

In another submission to the High Court, Professor John Mulvaney asserted that "the region promises to be a veritable laboratory for research into the society of early Homo sapiens, no less than the upper Palaeolithic sites in the Vézère valley in the French Dordogne, has proved for studies of European cultural origins." That the southwest has an archaeological content is not in question, but one does question the perspective. The caves of the Dordogne, the Lascaux Caves, are truly cultural treasure houses. It is generally agreed that they are special caves that were not used for general habitation, and in fact they contain remarkably few implements and animal remains. Archaeologists consider that these caves were used for religious activities, which produced magnificant examples of prehistoric art, with paintings and engravings of animals and vestiges of animals in colours that are fine, clear and vivid today. By contrast, the Franklin Valley caves merely record occupation by hunting parties, and so far no evidence of art or cultural activity has been found.

The proper perspective is that the Franklin Caves are only a few of a number of similar caves that were occupied by early man in the southwest. In spite of this, archaeologists maintained that the Franklin Caves and their deposits were of such uniqueness and cultural value that only total preservation in situ was acceptable. This argument was part of the successful campaign to stop the power project. Clearly the attitude adopted lacked scientific objectivity and emphasizes the wide gap between truth and verisimilitude when science is subordinated to promoting a course.

The social and economic cost of influencing public opinion are obviously great. Therefore, archaeologists can only continue to receive public support if the information the community receives is scientifically correct and sustainable. There must be a balance between the legitimate desire of archaeologists to preserve the relics in situ and the development needs of society, which can specify that some relics be preserved by undisturbed recovery. To achieve this end all groups must work together in a spirit of scientific cooperation.

\section{S.J. PATERSON}

Chief Geologist,

Hydro-Electric Commission,

Hobart, Tasmania, Australia

\section{Not as it seams!}

SIR - As an "occasional" cricketer who has been distinctly awestruck by the movement of the ball in the air - especially in damp conditions - I am disappointed that R. D. Mehta et al. (Nature 303, 787; 1983) were unable to account for the phenomenon.

One possible explanation is a temperature differential induced by the bowler through rubbing one side of the ball. This hemisphere apparently becomes quite hot and may provide an extra asymmetrical pressure on the ball through the localized effect of the heated hemisphere on the laminar flow of air over the ball, thus the ball would mimic an aerofoil. Perhaps this effect is in some way enhanced in damp conditions.

Mehta et al. may like to consider this aspect in addition to their estimation of the impact of the seam itself on the ball movement. Especially as the main weakness of their hypothesis is that it offers as an explanation of the problem of extra movement in humid conditions the claim that it is either enhanced backspin increased by damp conditions improving the bowler's grip (a seemingly weak explanation as humid conditions could increase sweating and reduce the bowler's grip), or that increased swing in humid conditions is an optical illusion. If the latter explanation is to be upheld, surely they should at least provide some indication as to how this illusion occurs, as it is apparently widespread.

BARRIE PEARSON 13 Knoll Cottage Caravan Park, Winfrith, Dorchester, Dorset DT2 8LD, UK 